\title{
PRELIMINARY REFERENCE PROCEDURE AND THE SCOPE OF JUDICIAL REVIEW OF THE EUROPEAN COURT OF HUMAN RIGHTS
}

\author{
Helena Majić, MSc, Legal Adviser, Lecturer \\ Constitutional Court of the Republic of Croatia \\ Trg svetog Marka 4, 10000 Zagreb \\ helena_majic@usud.hr; helenamajic@yahoo.com
}

\author{
Ljerka Mintas Hodak, PhD, Associate Dean \\ Zagreb Scool of Economics and Management \\ Jordanovac 110, 10000 Zagreb \\ ljerka.mintas-hodak@inet.hr
}

\begin{abstract}
The purpose of this paper is to examine the scope of the ECtHR's review of preliminary reference procedure provided for in Article 267 TFEU, insofar as it concerns the right to a fair trial and other procedural safeguards read into substantive rights of the ECHR. In Ullens de Schooten and Rezabek v. Belgium, the ECtHR established the principles of its review under Article 6(1) ECHR in connection to the obligation of the national courts to refer the question for a preliminary ruling. This paper analyses the scope of protection of the right to a fair trial in the context of the national court's failure to refer a question to the CJEU for a preliminary ruling, in particular in the light of the CJEU's Cilfit case law and additional obligations imposed on the national courts by the ECtHR that supplement the standards set out in the CJEU's jurisprudence. The reason behind circumventing the applicability of the right to an effective remedy (Article 13 ECHR) to the preliminary reference procedure is being ellaborated as well, especially with respect to the CJEU's finding that a request for preliminary ruling does not constitute a mean of redress available to the parties. Furthermore, this paper discusses whether the preliminary reference procedure can be considered as a procedural safeguard read into substantive rights of the ECHR. In connection to the latter, the interrelation between preliminary reference procedure and two principles - the principles of subsidiarity and equivalent protection - is analysed.
\end{abstract}

Keywords: preliminary reference procedure, right to a fair trial, presumption of equivalence, European Court of Human Rights, Court of Justice of the European Union 


\section{INTRODUCTION}

It is now settled case law of the European Court of Human Rights (hereinafter: ECtHR) that an absolute right to have a case referred to the Court of Justice of the European Union (hereinafter: CJEU) cannot be derived from the provisions of the ECHR, nor the duty of the national courts to refer a question for a preliminary ruling pursuant to Article 267 of the Treaty on the Functioning of the European Union (hereinafter: TFEU). ${ }^{1}$ Furthermore, the (European) Convention for the Protection of Human Rights and Fundamental Freedoms (hereinafter: ECHR) does not guarantee the right to have a case, which was referred to the CJEU, decided by a preliminary ruling, because a national court may simply withdraw the request for a preliminary ruling from the CJEU. ${ }^{2}$ However, national courts are not exempted from the duty to respect the principle of fairness inherent to the right to a fair trial. The latter principle may be infringed where the refusal to seek a preliminary ruling from the CJEU deems unreasonable or arbitrary. ${ }^{3}$ This paper, however, will not focus only on the arbitrariness of the refusal to refer, but all relevant aspects of the right to a fair trial will be taken into consideration.

\section{PRELIMINARY REFERENCE PROCEDURE AND THE RIGHT TO A FAIR TRIAL}

\subsection{Does Article 6(1) ECHR guarantee access to the CJEU?}

If there is no right under Article 6(1) ECHR to obtain a preliminary ruling, is it possible to assess the refusal to refer within the meaning of the right of access to the court? In Züchner v. Germany, the ECtHR ascertained that the refusal could be, in principle, examined in connection to the right to a "tribunal established by law". ${ }^{4}$ However, in Jansen and Verschueren-Jansen v. Netherlands, the ECtHR concluded that the scope of its review shall be limited only to the question whether the applicants had access to a national court competent to decide on the request

1 See, for example, decisions in the cases of John v. Germany (2007); Ferreira Santos Pardal v. Portugal (2012); Stichtung Mothers of Srebrenica and Others v. Netherlands (2013), par. 172; This opinion was founded upon previous case law on the "right to obtain a preliminary ruling“ from another domestic or international authority, e.g. Coëme and Others v. Belgium (2000), par. 114 and Wynen and Other v. Belgium (2001), par. 41-43

2 See the judgment Pafitis and Others v. Grece (1998), par. 111

3 See, for example, decisions in the cases of Schweighofer and Others v. Austria (2001), Canela Santiago v. Spain (2001), Bakker v. Austria (2003), De Bruyn v. Netherlands (1999), and John, op.cit. note 1; See also Valutyte, R., State liability for the infringment of the obligation to refer for a preliminary ruling under the European Convention on Human Rights, Jurisprudence, Vol. 19, No. 2, 2012, pp. 10-11

4 Decision Züchner v. Federal Republic of Germany (1987), par. 3 
for a referral..$^{5}$ Since the preliminary reference procedure is not conceived by EU law as a remedy providing direct access to the CJEU, the right of access to the latter cannot be guaranteed under Article 6(1) ECHR. ${ }^{6}$

\subsection{Prohibition of arbitrariness and the right to a reasoned decision}

The general prohibition of arbitrariness is closely related to the right to a reasoned decision. In its early case law, the ECtHR ascertained that as long as the national courts provide reasons for the refusal to seek a preliminary ruling, it will not deem the refusal arbitrary. Where a national court finds that the question raised by the applicant falls outside the scope of application of EU law, its finding will suffice to the standard of a reasoned decision. ${ }^{7}$ The ECtHR reached the same conclusion in DIVAGSA Company v. Spain where the matter brought before a national court was acte clair with respect to the relevant case law of the CJEU. ${ }^{8}$

There is only one situation in which the national courts are not required to adhere strictly to the standard of a reasoned decision, that being in the case of an applicant who failed to request expressly a referral to the CJEU, or failed to adduce precise reasons thereto. ${ }^{9}$ Therefore, the request for a referral must be sufficiently substantiated. Where the applicant complained of interpretation of relevant national law, instead of stating the question on interpretation of EU law, the national court was exempted from the duty to adduce the reasons for non-referral. ${ }^{10}$ General remarks as to the incompatibility of the impugned decision with EU law cannot suffice either. ${ }^{11}$ Due to the non-exhaustion rule, an applicant must submit a request and raise a complaint on non-referral before a competent national authority. ${ }^{12}$ However, he may do so in the latest stage of national proceedings before a constitutional court. ${ }^{13}$

The Ullens de Schooten and Rezabek v. Belgium case provided the ECtHR an opportunity to clarify which duties are conferred on the national courts by the right to a reasoned decision. It is a seminal case because the ECtHR decided to explain

\footnotetext{
5 Decision Jansen and Verschueren-Jansen v. Netherlands (1993), par. 1

6 For a critical review on access of the individuals to the CJEU, see Galera, S., El derecho a un juicio justo en el Derecho de la Unión Europea: luces y sombras, Revista de Derecho Político, No. 87, 2013, pp. 63-65

7 See, for example, decisions Moosbrugger v Austria (2000), par. 2; and Canela Santiago v Spain (2001)

8 Decision DIVAGSA Company v. Spain (1993), extracts

9 Decision in John

10 Decision Matheis v. Germany (2005), par. 3

11 See, in particular, the judgement in Wallishauser v. Austria No. 2 (2013), par. 85

12 See the decision in Mens and Mens-Hoek $v$. Netherlands (1998), par. 2

13 Decision Herma v. Germany (2009)
} 
for the very first time, in the judgment on the merits of the case, the meaning of the concept of arbitrariness in context of the preliminary reference procedure. ${ }^{14}$

The refusal to refer is arbitray „where there has been a refusal even though the applicable rules allow no exception to the principle of preliminary reference or no alternative thereto, where the refusal is based on reasons other than those provided for by the rules, and where the refusal has not been duly reasoned in accordance with those rules". ${ }^{15}$

Furthermore, the ECtHR departed from general standard of sufficient or relevant reasons and, in the light of Cilfit case law, has established more stringent standards which require special quality of the reasons adduced by the national courts. From there on, the ECtHR requires that the national courts „indicate the reasons why they have found that the question is irrelevant, that the (EU) law provision in question has already been interpreted by the Court of Justice, or that the correct application of (EU) law is so obvious as to leave no scope for any reasonable doubt" ${ }^{16}$ Thus, the ECtHR declared itself competent to review case by case whether the national courts observe the Cilfit criteria and the acte claire principle. ${ }^{17}$

Meanwhile, it must be emphasised that the Ullens de Schooten judgment has established the criteria of quality, not quantity. Depending on the circumstances of an individual case, summary reasoning of the refusal to refer may suffice. ${ }^{18}$ In this connection, in Harisch v. Germany the ECtHR found no violation Article 6(1) ECHR even though the Federal Court of Justice as the court of last resort within the meaning of Article 267 TFEU barely provided any reasons for non-referral. Thus because the impugned decision of the superior court was procedural by its nature and the ECtHR was satisfied that the lower appelate court had provided extensive reasons for non-referral. ${ }^{19}$ The ECtHR accepted "that the reasons for a

14 For detailed circumstances of the case, see judgment Ullens de Schooten and Rezabek v. Belgium (2011), par. 10-13

15 Ibid., par. 59; See also the judgment in Baydar v. Netherlands (2018), par. 39; As to the interpretation of those criteria in the case law of German Federal Court, see Valutyte, R., Legal Consequences for the Infringement of the Obligation to Make a Reference for a Preliminary Ruling, Jurisprudence, Vol. 19, No. 3, 2012, p. 1175

16 Judgment in Ullens de Schooten, par. 62; See also Derlen, M.; Lindholm, J. (eds.), The Court of Justice of the European Union: Multidisciplinary Perspectives, Hart Publishing, Oxford and Portland Oregon, 2018 , p. 22

17 See also Broberg, M.; Fenger, N., Preliminary references to the Court of Justice of the European Union and the right to a fair trial under Article 6 ECHR, European Law Review, Vol. 41, No. 4, 2016, pp. 605-606

18 See the decision in the case of Stichtung Mothers of Srebrenica, par. 173-174; and the judgment in Baydar, par. 43, 45

19 Harisch v. Germany (2019), par. 37-40 
decision by a superior court may be implied from the circumstances in some cases or from endorsement of the reasoning of the lower court". ${ }^{20}$

On the other hand, the ECtHR clarified that the assessment whether the national court's interpretation of EU law was „erroneus“ falls outside its jurisdiction. ${ }^{21}$ However, in Ramaer and Van Willigen v. Netherlands, the ECtHR assessed whether the national court's interpretation of EU law following the preliminary ruling delivered by the CJEU in the earlier stage of proceedings was, in general terms, arbitrary. $^{22}$

In its early case law, the ECtHR refrained from intervening in the national courts' refusal to refer to the CJEU and the vast majority of the complaints thereto were rejected as manifestly ill founded. Eventually, in Dhabbi v. Italy the ECtHR found that the refusal to seek a preliminary ruling violated Article 6(1) ECHR, but without any references to the Ullens de Schooten judgment. ${ }^{23}$ Thus because in Dhabbi the ECtHR did not deal with the concept of arbitrariness as it had been ellaborated in Ullens de Schooten. The alleged violation of the right to fair trial in Dhahbi was blatant because the national court did not observe that the applicant had submitted the request for a preliminary ruling, nor did it adress the applicant's submissions thereto in the impugned decision. ${ }^{24}$ Therefore, the national court infringed the applicant's right to a reasoned decision.

\subsection{Preliminary reference procedure and adversarial principle}

The Ullens de Schooten case is also significant with respect to the conclusion that the refusal to refer must adhere to the adversarial principle, another procedural safeguard of the right to a fair trial. ${ }^{25}$ The parties must be provided the opportunity

$20 \quad$ Ibid., par. 41

${ }_{21}$ Decision in Stichtung Mothers of Srebrenica, par. 65-66; See also par. 89-90 of the decision in Vergauwen and Others v. Belgium (2012) where the ECtHR concluded that: ,it is not for the Court to examine any errors that might have been committed by the domestic courts in interpreting or applying the relevant law"

22 Decision Ramaer and Van Willigen v. Netherlands (2012), par. 104

23 Krommendijk, for example, criticised the latter approach. See more in Krommendijk, "Open Sesame!": Improving Access to the ECJ by Requiring National Courts to Reason their Refusals to Refer, European Law Review, Vol. 42, No. 1, 2017, pp. 46-62

24 Judgment Dhahbi v. Italy (2014), par. 31-33; In almost identical circumstances and for identical reasons, a violation of the right to a fair trial was found in the case of Schipani and Others $v$. Italy (2015), par. 69-72; For further comments on these cases, see Broberg, M.; Fenger, N., Preliminary references to the Court of Justice of the European Union and the right to a fair trial under Article 6 ECHR, European Law Review, Vol. 41, No. 4, 2016, pp. 602-603; and Konstadinides, T., The Rule of Law in the European Union: The Internal Dimension, Hart Publishing, London, 2017, p. 177.

25 Judgment in Ullens de Schooten, par. 66 
to submit the pleadings, or to respond to the submissions of the opposing party in connection to the referral. ${ }^{26}$ Therefore, the parties' submissions must be examined with due dilligence.

Another interesting issue as to the compliance with the adversarial principle arose in Cooperatieve Producentenorganisatie van de Nederlandse Kokkelvisserij U.A. v. Netherlands case where the applicant complained that the latter was violated because he was denied to respond to Advocate General's opinion in the proceedings before the CJEU. The ECtHR concluded that in so far as the applicant's complaints must be understood as being directed against the EU itself, they are inadmissible as incompatible with the provisions of the ECHR ratione personae. However, the ECtHR is not precluded from determining whether the alleged violation of adversarial principle before the CJEU could be imputed to the referring national court. Such conclusion was reached because the interference with the applicant's right to a fair trial may, in principle, be attributed to the national court's decision to seek a preliminary ruling. ${ }^{27}$

Therefore, the ECtHR is competent to review under Article 6(1) ECHR the effects that the proceedings before the CJEU might have had on the proceedings before a national court. In this regard the ECtHR examined whether the procedure before the CJEU was accompanied by guarantees which ensured equivalent protection of the applicant's right to a fair trial. With a view to the principle of equivalence, no violation of the right to a fair trial had been found. As the ECtHR pointed out, the protection of adversarial principle before the CJEU is not required to be identical to that provided by the ECHR. However, the ECtHR reviews whether the procedural safeguards of the right to a fair trial are observed by the CJEU. If there was an infrigment of the right to a fair trial found in the proceeding before the CJEU, it would be imputed to the Member State's domestic court, not the CJEU itself. ${ }^{28}$

26 Finding no violation in the case of De Bruyn, the ECtHR concluded: “...it does not appear that the applicant was unable or was insufficiently able to submit arguments based on rules emanating from the European Union which he considered relevant to the outcome of his case."

27 Decision Cooperatieve Producentenorganisatie van de Nederlandse Kokkelvisserij U.A. v. Netherlands (2009), par. 2-3; The latter decision was inspired by the case of Vermeulen v. Belgium (1996), in which a violation of the right to a fair trial was found because the applicant was deprived of an opportunity to reply to the advisory opinion of the advocate-general of a superior national court (par. 42-44); see also K. D. B. v. Netherlands (1998)

28 The ECtHR clarified: „Although thus prevented from examining the procedure before the ECJ in the light of Article $6 \mathbb{S} 1$ directly, the Court is not dispensed from considering whether the events complained of engaged the responsibility of the Kingdom of the Netherlands as a respondent party... The nexus between a preliminary ruling by the ECJ under Article 234 of the EC Treaty and the domestic proceedings which give rise to it is obvious. "., ibid., par. 3 


\subsection{Stay of proceedings and the right to a fair trial within reasonable time}

Once the case was referred to the CJEU for a preliminary ruling, domestic proceedings must be stayed. The stay of proceedings enables the CJEU to deliver a judgement having real effect on the outcome of a dispute which had invoked a question on interpretation of EU law. However, due to the CJEU's heavy caseload, the preliminary reference procedure contributes to the overall length of proceedings before national courts, thus raising a question whether the national proceedings that have been stayed after the referral conform to the right to a fair trial within reasonable time. In Pafitis and Others v. Greece, the European Commission of Human Rights concluded that national authorities cannot be held accountable for the delays which had occurred before the CJEU, provided that "the decision to make a preliminary reference was in conformity with the proper administration of justice ". ${ }^{29}$ The meaning of the latter „proper administration of justice“ prerequisite has not been clarified in the context of the national court's decision on referral. The Commission furthermore implied that it will not examine the national rules on the stay of proceedings, even if the case referred to the CJEU was urgent in facts and law.

This case, nevertheless, illustrates a good example of human rights becoming „devoid of any purpose". The CJEU pronounced on the request two years and seven months after the matter was referred to it, therefore contributing significantly to the overall length of proceedings. Having regard to short time that has been left to the national court to decide on the applicants' case within reasonable time, the ECtHR decided that the national courts cannot be held accountable for any delays that might have occured due to the proceedings conducted the CJEU. By taking no recourse to the lack of formal jurisdiction over the CJEU, the ECtHR has thus created a situation in which nobody can be held accountable for delays in domestic proceedings. ${ }^{30}$

Since the referral for a preliminary ruling also constitutes the exercise of judicial discretionary powers, thus even those parties who had opposed to it remain unprotected. Moreover, where the applicants insist on referral to the CJEU and submit additional pleadings which prolong the proceedings, those circumstances will be taken into consideration to their detriment in the ECtHR's assessment of the conduct of national authorities. ${ }^{31}$

\footnotetext{
29 Judgment in Pafitis, par. 111; See also the judgments in the cases of Koua Poirrez v. France (2003), par. 61

30 See also Broberg, M.; Fener, N., Preliminary References to the European Court of Justice, Oxford University Press, Oxford, 2014, pp. 278-279

31 Judgment Pedersen and Pedersen $v$ Denmark (2004), par. 51; see also the decision in T. Dalsgaard and J. Dalsgaard v. Denmark (2005)
} 


\section{THE REQUEST FOR A PRELIMINARY RULING - AN EFFECTIVE LEGAL REMEDY WITHIN THE MEANING OF ARTICLE 13 ECHR?}

According to the CJEU's Cilfit judgment, Article 267 TFEU does not provide for any means of legal redress in the proceedings before national courts. ${ }^{32}$

The first opportunity to conclude whether the proceedings provided for in Article 267 TFEU fall within the scope of application of Article 13 ECHR arose in Adams and Benn v. the United Kingdom where the applicants claimed that, due to the national court's decision to withdraw from the CJEU the questions referred, they were left without effective judical protection in so far as they had invoked an application of the relevant primary law provisions on free movement of persons to their case. ${ }^{33}$ The Commission for Human Rights noted that „the applicants' claim is based on a provision of a treaty which provides in general terms for freedom of movement of citizens of the EU" which cannot be considered as an arguable claim of a violation of the ECHR. Consequently, it was concluded that their complaints, in so far as they concerned Articles 6 and 13 ECHR, were incompatible ratione materiae with the ECHR. ${ }^{34}$

Furthermore, in Emesa Sugar N. V. v. Netherlands the European Commision, as an intervenor to the proceedings before the ECtHR, argued that „the preliminary ruling procedure was conceived as a dialogue between judges at the national and the Community level on a question of interpretation of EC law ". ${ }^{35}$ Unfortunately, the ECtHR did not advance that argument in connection to the applicability of Article 13 ECHR to the latter case.

Eventually, in Ullens de Schooten, the ECtHR reiterated that Article 6(1) ECHR implies the full panoply of safeguards which are stricter and thus absorb those

32 Case 283/81 Srl CILFIT and Lanificio di Gavardo SpA v Ministry of Health [1982] E.C.R. 3415, par. 9; For a critique of such solution and further recommendations, see Lacchi, C., Multilevel judicial protection in the EU and preliminary references, Common Market Law Review, Vol. 53, No. 3, 2016, pp. 679-707; and Silveira, A.; Perez Fernandes, S.; Preliminary References, Effective Judicial Protection and State Liability. What if the Ferreira da Silva Judgment Had not Been Delivered?, Revista de Derecho Comunitario Europeo, No. 54, 2016, pp. 641-648

33 Decision Adams and Benn v. the United Kingdom (1997)

34 Ibid., par. 2-3; This interpretation was directly overturned in the CJEU's Baumbast judgment. The latter court came to a conclusion that the freedom to reside or move freely within the territory of the Member States confers on the individuals the "rights which are enforceable by them and which the national court must protect". See Case C-413/99 Baumbast and $R v$. Secretary of State for the Home Department [2002] ECR I-7091, par. 86; On autonomous and directly effective right of movement and residence, see Craig, P.; de Burca, G., EU Law - Text, Cases and Material, Oxford University Press, Oxford, 2015, pp. 860-865

35 Decision Emesa Sugar N. V. v Netherlands (2005) 
of Article 13. For that reason, it concluded that the complaints of non-referral should be examined under Article 6(1) ECHR alone. ${ }^{36}$

\section{PRELIMINARY REFERENCE PROCEDURE AND THE PRINCIPLE OF SUBSIDIARITY}

Nevertheless, it must be emphasised that the ECtHR has never stated expressly that Article $13 \mathrm{ECHR}$ is not applicable to the preliminary reference procedure. The reason thereof, most probably, was to prevent limiting the scope of the ECtHR's review. It is important to notice that if the ECtHR had interpreted that a request for a preliminary ruling is an effective legal remedy within the meaning of Article 13 ECHR, it would have to examine, whenever proper interpretation of EU law is in the core of the applicant's complaint, whether all remedies provided for in domestic law were exhuasted prior to the application, including the request for a referral. Consequently, the ECtHR's scope of review on the matters concerning EU law would be limited by the principle of subsidiarity.

Therefore, the ECtHR would be deprived from its supervisory mechanisms whenever a Contracting Party claims that the complaints raised before the ECtHR fall clearly within the scope of application of EU law. Thus, for example, in $X$. S. A. v. Netherlands, the ECtHR refused to adress the Government's complaint as to the non-exhaustion of domestic remedies due to the applicant's failure to seek a preliminary ruling on interpretation of EU law. ${ }^{37}$

However, the latter does not mean that the ECtHR cannot apply the principle of subsidiarity with respect to the EU's legal order. It had applied it, but only in LAURUS INVEST HUNGARY KFT and Others v. Hungary where the proceedings were still pending before the CJEU. Taking into account the circumstances of the case, the ECtHR pointed out that "to substitute its own assessment for that of the national courts as guided by the CJEU, without awaiting the outcome of those proceedings, would be tantamount to ignoring its subsidiary role". ${ }^{38}$

\section{PRELIMINARY REFERENCE PROCEDURE AS A PROCEDURAL SAFEGUARD READ INTO SUBSTANTIVE RIGHTS GUARANTEED BY THE ECHR - THE REBUTTABLE PRESUMPTION OF EQUIVALENCE}

The question whether a refusal to refer for a preliminary ruling could be examined as a procedural safeguard read into substantive rights of the ECHR arose for the

\footnotetext{
36 Judgment in Ullens de Schooten, par. 52

37 Decision X. S.A. v. Netherlands (1994), par. 1

38 Decision LAURUS INVEST HUNGARY KFT and Others v. Hungary (2015), par. 42
} 
first time in Spiele v. Netherlands where the ECtHR concluded that the refusal to seek a preliminary ruling did not disclose any issue under Article 10 of the ECHR. ${ }^{39}$ Later on, in Chylinski and Others v. Netherlands the applicants suggested that their complaint should be examined under Article 5 of the ECHR. However, the application was declared inadmissible because the ECtHR ascertained that the request for a preliminary ruling could have had no bearing on the lawfulness of detention. ${ }^{40}$ Even though the ECtHR did not respond definitely to the applicants' question, it assessed the refusal to refer in connection to the lawfulness of detention, a concept inherent to the substantive right to liberty under Article 5 of the ECHR. Thus, the possibility of assessing the refusal to seek a preliminary ruling as a procedural safequard read into the substantive rights has not been ruled out by the ECtHR.

Meanwhile, the ECtHR found another, less explicit form of assessing the request for a referral as a procedural safeguard read into substantive rights of the ECHR. In the Bosphorus judgment the ECtHR has established the presumption of equivalent protection. Taking into account the protection of human rights afforded to the individuals by the Charter of Fundamental Rights and the primary law of the $\mathrm{EU}$, as well as the role and powers of the CJEU, the ECtHR found that that protection is, in principle, equivalent (comparable) to that for which the ECHR provides. ${ }^{41}$ The latter presumption can be rebutted only if the protection of human rights provided for in the EU legal order can be regarded as manifestly deficient. ${ }^{42}$

Furthermore, in Michaud v. France the ECtHR subjected the presumption of equivalence to two conditions: 1 . absence of discretionary powers in application of EU law on the part of domestic authorities; 2. deployment of the full potential of the supervisory mechanism provided for by EU law. ${ }^{43}$ The second condition relates especially to the judicial review of the CJEU. The Michaud judgment was

39 Decision Spiele v. Netherlands (1997), par. 1

40 Decision Chylinski and Others v. Netherlands (2015), par. 48

${ }^{41}$ See more in Ravasi, E., Human Rights Protection by the Ecthr and the Ecj: A Comparative Analysis in Light of the Equivalency Doctrine, Brill - Nijhoff, Leiden, 2017, pp. 385-388; and Tridimas, T.; Schütze, R. (eds.), Oxford Principles of European Union Law: Volume 1: The European Union Legal Order, Oxford, 2018, pp. 404-405

42 See Bosphorus Hava Yollar Turizm ve Ticaret Anonim Şirketi (2005), par. 156, 159-165; For a comment on this concept in Bosphorus case law, see Callewaert, J., The European Convention on Human Rights and European Union Law: a Long Way to Harmony, European Human Rights Law Review, No. 6, 2009, pp. 772-773; As to the application of this concept in the Avotinšs case, see Gragl, P., An Olive Branch from Strasbourg? Interpreting the European Court of Human Rights' Resurrection of Bosphorus and Reaction to Opinion 2/13 in the Avotinš Case: ECtHR 23 May 2016, Case No. 17502/07, Avotiňs v Latvia, European Constitutional Law Review, Vol. 3, No. 3, p. 559

43 Judgment Michaud v. France (2012), par. 113-115 
interesting in regard to the reason for which the ECtHR found that the presumption of equivalence was rebutted. It reiterated that the circumstances of the Bosphorus case differ from those in the Michaud case in connection to the national court's decision to refer the question for a preliminary ruling. While in the Bosphorus case the national court referred the questions on interpretation of EU law to the CJEU, in the Michaud case the applicant's request for a referral to the CJEU had been rejected. For that particular reason, the ECtHR stated: „The Court is therefore obliged to note that because of the decision of the Conseil d'Etat not to refer the question before it to the Court of Justice for a preliminary ruling, even though that court had never examined the Convention rights in issue, the Conseil d'Etat ruled without the full potential of the relevant international machinery for supervising fundamental rights - in principle equivalent to that of the Convention - having been deployed. In the light of that choice and the importance of what was at stake, the presumption of equivalent protection does not apply. ". ${ }^{44}$

In order to avoid possible misinterpretations of the Michaud judgment, in Avotinšs v. Latvia the ECtHR clarified that the refusal to seek a preliminary ruling does not preclude the application of the presumption of equivalence in any circumstances. ${ }^{45}$ In the instant case it took into consideration that the applicant failed to adress properly the reasons for which the interpretion of EU law is required. Furthermore, it stated that in the Michaud case the applicant raised a question whether the impugned provisions of EU law are compatible with the ECHR and that distinctive issue had never been examined by the CJEU in its previous case law. ${ }^{46}$

Even though the ECtHR had not stated that the refusal to seek a preliminary ruling may be assessed as a procedural safeguard read into substantive rights of the ECHR, it nevertheless acknowledged that such refusal may rebut the presumption of equivalence and lead to deployment of full protective machinery of the ECHR. Consequently, it may be concluded that the preliminary reference procedure, at least indirectly, has been recognised by the ECtHR as a procedural safequard relevant to the assessment on conformity of EU law to the substantive rights protected by the ECtHR.

\footnotetext{
$44 \quad$ Ibid., par. 115

45 See also Jelinić, Z.; Knol Radoja, K., Mutual Recognition of Judicial Decisions and the Right to a Fair Trial with Special Focus on the ECHR's Findings in the Case of Avotins v Latvia, EU and Comparative Law Issues and Challenges, No. 2, pp. 579-582

46 Judgment Avotinš v. Latvia (2016), par. 110-111
} 


\section{CONCLUSIONS ON THE SCOPE OF REVIEW OF THE ECTHR}

The ECtHR's review is a self-restrained judicial review of the preliminary reference procedure at the level of national courts. The fact that the ECtHR will not establish any form of review of the proceedings conducted by the CJEU became obvious in Emesa Sugar N. V. Even though the ECtHR avoided to respond to the European Commission's argument that it lacks jurisdiction over the acts of the EU's institutions, the ECtHR's case law does not show a frank restraint from intervening in the matters which could be considered to fall within an exclusive jurisdiction of the CJEU. ${ }^{47}$ The reason thereof can be found in the Bosphorus judgment where the ECtHR indirectly stated that, due to the limited access of individuals to the CJEU, the ECtHR retained the role of the ultimate guardian of the respect for human rights in the EU. ${ }^{48}$

In its early case law, the ECtHR founded its judicial review of early stages of the preliminary reference procedure upon a general prohibition of arbitrariness (the right to a reasoned decision) as it is being interpreted withing the meaning of the right to a fair trial. In this regard the ECtHR follows the methodology developed in Cilfit case law and has abandoned the autonomus concepts of the ECHR as a method of interpretation. Therefore, the ECtHR acknowledges the autonomy of the EU's legal order and adheres to the criteria developed by the CJEU.

However, the scope of the ECtHR's review of is not limited exclusively to observance of the national courts' duty to reason the decision on non-referral.

The ECtHR's case law indicates that observance of the adversarial priniciple at any stage of national proceedings prior to, and after referral, may be subjected to its scrutiny if it is affected by the proceedings conducted before the CJEU.

Even though the ECtHR has not accepted the possibility of applying the principle of subsidiarity and the non-exhaustion rule to the complaints which raise an issue of proper interpretation of EU law, it has acknowledged that the preliminary reference procedure pending before the CJEU may preclude him from examining the merits of such complaints. Thus because the purpose of the ECtHR's review is not to substitute it for that of the CJEU.

Finally, the Michaud judgment has indicated that the ECtHR's review of the preliminary reference procedure may be extended beyond Article 6(1) ECHR. The latter case revealed that a mere failure of a national court to seek a preliminary rul-

\footnotetext{
47 Decision Emesa Sugar N. V; See also Kuhnert, K., Bosphorus - Double standards in European human rights protection?, Utrecth Law Review, Vol. 2, No. 2, 2006, p. 184

48 See judgment in Bosphorus, par. 162
} 
ing may rebut the presumption of equivalence and lead the ECtHR to assess the conformity of EU law (and national law derived from it) to the ECHR. Therefore, a decision on non-referral does not trigger the applicability of Article 6(1) ECHR only, but also raises serious concerns about observance of substantive rights guaranteed by the ECHR.

\section{REFERENCES}

\section{BOOKS AND ARTICLES}

1. Broberg, M., National Courts of Last Instance Failing to Make a Preliminary Reference : - the (possible) consequences flowing therefrom, European Public Law, Vol. 22, No. 2, 2016, pp. 243-256

2. Broberg, M.; Fenger, N., Preliminary references to the Court of Justice of the European Union and the right to a fair trial under Article 6 ECHR, European Law Review, Vol. 41, No. 4, 2016, pp. 599-607

3. Broberg; M., Fener, N., Preliminary References to the European Court of Justice, Oxford University Press, Oxford, 2014

4. Callewaert, J., The European Convention on Human Rights and European Union Law: a Long Way to Harmony, European Human Rights Law Review, No. 6, 2009, pp. 769-783

5. Craig, P.; de Burca, G., EU Law - Text, Cases and Material, Oxford University Press, Oxford, 2015, pp. 860-865

6. Derlen, M.; Lindholm, J. (eds.), The Court of Justice of the European Union: Multidisciplinary Perspectives, Hart Publishing, Oxford and Portland Oregon, 2018

7. Galera, S., El derecho a un juicio justo en el Derecho de la Unión Europea: luces y sombras, Revista de Derecho Político, No. 87, 2013, pp. 49-76

8. Gragl, P., An Olive Branch from Strasbourg? Interpreting the European Court of Human Rights' Resurrection of Bosphorus and Reaction to Opinion 2/13 in the Avotinš Case: ECtHR 23 May 2016, Case No. 17502/07, Avotiņš v Latvia, European Constitutional Law Review, Vol. 3, No. 3, pp. 551-567

9. Jelinić, Z., Knol Radoja, K., Mutual Recognition of Judicial Decisions and the Right to a Fair Trial with Special Focus on the ECHR's Findings in the Case of Avotinšs v Latvia, EU and Comparative Law Issues and Challenges, No. 2, pp. 571-585

10. Konstadinides, T., The Rule of Law in the European Union: The Internal Dimension, Hart Publishing, London, 2017

11. Krommendijk, "Open Sesame!": Improving Access to the ECJ by Requiring National Courts to Reason their Refusals to Refer, European Law Review, Vol. 42, No. 1, 2017, pp. 46-62

12. Kuhnert, K., Bosphorus - Double standards in European human rights protection?, Utrecth Law Review, Vol. 2, No. 2, 2006, pp.177-189

13. Lacchi, C., Multilevel judicial protection in the EU and preliminary references, Common Market Law Review, Vol. 53, No. 3, 2016, pp. 679-707 
14. Ravasi, E., Human Rights Protection by theECtHR and ECJ : A Comparative Analysis in Light of the Equivalency Doctrine, Brill - Nijhoff, Leiden, 2017

15. Silveira, A.; Perez Fernandes, S.; Preliminary References, Effective Judicial Protection and State Liability. What if the Ferreira da Silva Judgment Had not Been Delivered?, Revista de Derecho Comunitario Europeo, No. 54, 2016, pp. 631-666

16. Tridimas, T.; Schütze, R. (eds.), Oxford Principles of European Union Law: Volume 1: The European Union Legal Order, Oxford, 2018

17. Valutyte, R., State liability for the infringment of the obligation to refer for a preliminary ruling under the European Convention on Human Rights, Jurisprudence, Vol. 19, No. 2, 2012, pp. $7-20$

18. Valutyte, R., Legal Consequences for the Infringement of the Obligation to Make a Reference for a Preliminary Ruling, Jurisprudence, Vol. 19, No. 3, 2012, pp. 1171-1186

\section{COURT OF JUSTICE OF THE EUROPEAN UNION}

1. Case C-413/99 Baumbast and R v. Secretary of State for the Home Department [2002] ECR I-7091

2. Case 283/81 Srl CILFIT and Lanificio di Gavardo SpA v Ministry of Health [1982] E.C.R. 3415

\section{ECHR}

\section{Decisions retrieved from HUDOC}

1. Zuchner v. Federal Republic of Germany, No. 11402/85, 02.03.1987

2. Jansen and Verschueren-Jansen v. Netherlands, No. 17239/90, 31.03.1993

3. Vermeulen v. Belgium, No. 19075/91, 20.02.1996

4. DIVAGSA Company v. Spain, No. 20631/92, 12.05.1993

5. X. S. A. v. Netherlands, No. 21472/93, 11.01.1994

6. Coëme and Others v. Belgium, Nos. 32492/96 et al., 22.06.2000

7. Mens and Mens-Hoek v. Netherlands, No. 34325/96, 20.05.1998

8. Wynen and Others v. Belgium, No. 32576/96, 18.09.2001

9. Spiele v. Netherlands, No. 31467/96, 22.10.1997

10. Adams and Benn v. the United Kingdom, Nos. 28979/95 and 30343/96, 13.01.1997

11. Schweighofer and Others v. Austria, Nos. 35673/97 et al., 09.10.2001

12. Bakker v. Austria, No. 43454/98, 10.04.2003

13. De Bruyn v. Netherlands, No. 37826/97, 02.02.1999

14. Moosbrugger v. Austria, No. 44861/98, 25.01.2000

15. Canela Santiago v. Spain, No. 60350/00, 04.10.2001

16. Emesa Sugar N. V. v Netherlands, No. 62023/00, 13.01.2005

17. Matheis v. Germany, No. 73711/01, 01.02.2005 
18. T. Dalsgaard and J. Dalsgaard v. Denmark, No. 42986/02, 29.09.2005

19. John v. Germany, No. 15073/03, 13.02.2007

20. Vergauwen and Others v. Belgium, No. 4832/04, 10.04.2012

21. Cooperatieve Producentenorganisatie van de Nederlandse Kokkelvisserij U.A. v. Netherlands, No. 13645/05, 20.01.2009

22. Herma v. Germany, No. 54193/07, 08.12.2009

23. Ferreira Santos Pardal v. Portugal, No. 30123/10, 04.09.2012

24. Stichtung Mothers of Srebrenica and Others v. Netherlands, No. 65542/12, 11.06.2013

25. Ramaer and Van Willigen v. Netherlands, No. 34880/12, 23.10.2012

26. Chylinski and Others v. Netherlands, Nos. 38044/12 et al., 21.04.2015

27. LAURUS INVEST HUNGARY KFT and Others v. Hungary, Nos. 23265/13 et al., 08.09.2015

\section{Judgments retrieved from HUDOC:}

1. Pafitis and Others v. Grece, No. 20323/92, 26.02.1998

2. K. D. B. v. Netherlands, No. 21981/93, 27.03.1998

3. Koua Poirrez v. France, No. 40892/98, 30.09.2003

4. Pedersen and Pedersen v Denmark, No. 68693/01, 14.10.2004

5. Bosphorus Hava Yolları Turizm ve Ticaret Anonim Şirketi (GC), No. 45036/98, 30.06.2005

6. Wallishauser v. Austria 2, No. 14497/06, 20.06.2013

7. Ullens de Schooten and Rezabek v. Belgium, Nos. 3989/07 and 38353/07, 20.09.2011

8. Avotinš̌ v. Latvia (GC), No. 17502/07, 23.05.2016

9. Dhahbi v. Italy, No. 17120/09, 08.04.2014

10. Schipani and Others v. Italy, No. 38369/09, 21.07.2015

11. Michaud v. France, No. 12323/11, 06.12.2012

12. Baydar v. Netherlands, No. 55385/14, 24.04.2018

13. Harisch v. Germany, No. 50053/16, 11.04.2019 